\title{
An ultrastructural study of the urinary bladder in children correlated with histological, bacteriological, and clinical findings
}

\author{
MARGARET HAYNES, P. A. TROTT ${ }^{1}$, A. K. M. S. ISLAM, AND G. HIRST \\ From the Department of Pathology, Institute of Urology, London
}

SYNOPSIS Bladder biopsies from six boys without a history of urinary tract infection were taken during hypospadias repair operations and examined by electron microscopy. The ultrastructure of the epithelium, which was presumed to represent the normal, is described in detail and compared with the reported findings in other mammalian species. The appearances are generally similar although in our material the luminal membrane of the superficial cells was thicker than that surrounding the other epithelial cells but not asymmetrical. We observed membrane-coating granules which have not been reported before in bladder epithelium.

The appearances of the normal bladder are compared to those seen in 24 children with urinary infection. In the presence of acute infection the large heterogeneous secondary lysosomes which are present in the intermediate and superficial cells of the normal bladder are reduced in number and the amount of rough endoplasmic reticulum is increased.

The electron microscopic appearances of the urinary bladder epithelium of several mammalian species are well documented but there are few reports of similar studies in man. Fulker, Cooper, and Tanaka (1971) described the ultrastructure of human transitional cell carcinoma and commented on the appearance of the epithelium in the non-neoplastic areas, and Battifora, Eisenstein, and McDonald (1964) studied tissue obtained by cystoscopic biopsy from 13 adults, some with benign prostatic hypertrophy but all free of bladder neoplasia. However, patients with obstructive disease of the urinary tract are not entirely suitable for study of the normal bladder and it is the purpose of this paper to describe the bladder epithelium obtained from six boys undergoing surgery for congenital lesions of the lower urethra in whom there was no evidence of other urological abnormality. The ultrastructural and histological appearances are described and compared with those seen in a group of 24 children with symptoms of urinary infection. The cystoscopic findings and the results of bacteriological investigations are also recorded.

1Present address and address for reprints: Department of Histopathology, Royal Marsden Hospital, Fulham Road, London.

Received for publication 28 October 1974.

\section{Materials and Methods}

CLINICAL

Specimens of bladder mucosa were obtained from응 the trigone at the time of suprapubic urinary: diversion in six boys aged 2-13 years (table I) who were undergoing repair of hypospadias and had no clinical or bacteriological evidence of past or present urinary tract infection. Eighteen girls and six boys $ᄋ$ formed a control group in which the majority had recurrent urinary tract infection usually with vesico-o ureteric reflux and which included two children (cases 7 and 8) with bladder symptoms but noo definite evidence of infection. Biopsies were taken $N$ of lesions seen either at open operation during a N reconstructive procedure or transurethrally. When no abnormality was noted, tissue was obtained at random from the trigone.

After collecting a cystoscopic specimen of urine for bacteriological examination, two pieces of tissue, $\square$ each between $0 \cdot 1$ and $1 \mathrm{~cm}$ in diameter with an average maximum diameter of $0.5 \mathrm{~cm}$, were taken $\vec{\Omega}$ with Brown Buerger rongeur forceps. One was placed immediately in glutaraldehyde fixative $(3 \%$ glutaraldehyde in $0.1 \mathrm{M}$ cacodylate buffer, $\mathrm{pH} 7 \cdot 2$, 


\begin{tabular}{|c|c|c|c|c|c|c|c|c|}
\hline $\begin{array}{l}\text { Case } \\
\text { No. }\end{array}$ & $\begin{array}{l}\text { Age } \\
\text { (years) }\end{array}$ & $\operatorname{Sex}$ & $\begin{array}{l}\text { Clinical } \\
\text { Diagnosis }\end{array}$ & $\begin{array}{l}\text { Bladder } \\
\text { Mucosa at } \\
\text { Cystoscopy }\end{array}$ & $\begin{array}{l}\text { Light } \\
\text { Microscopy } \\
\text { Groups (L) }\end{array}$ & $\begin{array}{l}\text { Electron } \\
\text { Microscopy } \\
\text { Groups (E) }\end{array}$ & $\begin{array}{l}\text { Bacteriology } \\
\text { Groups }(B)\end{array}$ & $\begin{array}{l}\text { Previous } \\
\text { Infection } \\
\text { (Months) }\end{array}$ \\
\hline $\begin{array}{c}1-6 \\
7 \\
8\end{array}$ & $\begin{array}{c}2-13 \text { range } \\
7 \\
6\end{array}$ & $\begin{array}{l}\mathbf{M} \\
\mathbf{F} \\
\mathbf{M}\end{array}$ & $\begin{array}{l}\text { Hypospadias } \\
\text { Enuresis } \\
\text { Paraureteric }\end{array}$ & $\begin{array}{l}\text { Normal } \\
\text { Normal }\end{array}$ & $\begin{array}{l}1 \\
2\end{array}$ & $\begin{array}{l}1 \\
1\end{array}$ & $\begin{array}{r}* 1 \\
1\end{array}$ & $\begin{array}{l}\text { Never } \\
\text { Never }\end{array}$ \\
\hline & & & diverticulum & Normal & 1 & 1 & 1 & Never \\
\hline 9 & 10 & $\mathbf{F}$ & $\begin{array}{l}\text { Urinary tract } \\
\text { infection }\end{array}$ & Normal & 1 & 1 & 1 & 12 \\
\hline 10 & 6 & $\mathbf{F}$ & $\begin{array}{l}\text { Atonic bladder } \\
\text { urinary tract } \\
\text { infection } \\
\text { Urinary tract }\end{array}$ & Normal & 3 & 2 & No CSU & 2 \\
\hline 12 & 7 & $\mathbf{F}$ & $\begin{array}{l}\text { infection } \\
\text { Enuresis; }\end{array}$ & Normal & 1 & 1 & 1 & 2 \\
\hline 13 & 9 & $\mathbf{M}$ & $\begin{array}{l}\text { urinary tract } \\
\text { infection } \\
\text { Hypospadias; }\end{array}$ & $\begin{array}{l}\text { Normal } \\
\text { Small }\end{array}$ & 3 & 2 & 2 & 3 \\
\hline 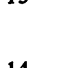 & & & $\begin{array}{l}\text { Urinary tract } \\
\text { infection }\end{array}$ & $\begin{array}{l}\text { translucent } \\
\text { lesions }\end{array}$ & 3 & 3 & No CSU & $t<1$ \\
\hline 14 & 8 & $\mathbf{F}$ & $\begin{array}{l}\text { Urinary tract } \\
\text { infection }\end{array}$ & $\begin{array}{l}\text { Small solid } \\
\text { lesions; } \\
\text { erythema; } \\
\text { oedema }\end{array}$ & 2 & 3 & 3 & 5 \\
\hline 15 & 8 & $\mathbf{F}$ & $\begin{array}{l}\text { Urinary tract } \\
\text { infection }\end{array}$ & $\begin{array}{l}\text { Solid lesions; } \\
\text { erythema }\end{array}$ & 3 & 3 & 3 & 6 \\
\hline 16 & 8 & $\mathbf{F}$ & $\begin{array}{l}\text { Urinary tract } \\
\text { infection }\end{array}$ & Normal & 2 & 3 & 3 & Never \\
\hline 17 & 5 & $\mathbf{F}$ & $\begin{array}{l}\text { Reflux; } \\
\text { urinary tract } \\
\text { infection } \\
\text { Reflux. }\end{array}$ & Normal & 2 & 1 & 1 & 5 \\
\hline 18 & 6 & $\mathbf{M}$ & $\begin{array}{l}\text { Reflux; } \\
\text { urinary tract } \\
\text { infection } \\
\text { Refiux; }\end{array}$ & Normal & 2 & 1 & 1 & 24 \\
\hline & & & $\begin{array}{l}\text { urinary tract } \\
\text { infection }\end{array}$ & Normal & 2 & 2 & 1 & 2 \\
\hline 20 & 4 & $\mathbf{F}$ & $\begin{array}{l}\text { Reflux; } \\
\text { urinary tract } \\
\text { infection }\end{array}$ & $\begin{array}{l}\text { Translucent } \\
\text { lesions }\end{array}$ & 3 & 2 & No CSU & $t<1$ \\
\hline 21 & 7 & $\mathbf{F}$ & $\begin{array}{l}\text { Reflux; } \\
\text { urinary tract } \\
\text { infection } \\
\text { Reflux; }\end{array}$ & Erythema & 3 & 2 & 1 & 1 \\
\hline & & & $\begin{array}{l}\text { urinary tract } \\
\text { infection }\end{array}$ & $\begin{array}{l}\text { Translucent } \\
\text { lesions }\end{array}$ & 3 & 2 & 2 & 2 \\
\hline 23 & 15 & $\mathbf{F}$ & $\begin{array}{l}\text { Reflux; } \\
\text { urinary tract } \\
\text { infection } \\
\text { Reflux; }\end{array}$ & Erythema & 2 & 2 & 3 & 3 \\
\hline 24 & 7 & $\mathbf{F}$ & $\begin{array}{l}\text { Reflux; } \\
\text { urinary tract } \\
\text { infection }\end{array}$ & $\begin{array}{l}\text { Translucent } \\
\text { lesions }\end{array}$ & 1 & 2 & 3 & 6 \\
\hline 25 & 14 & $\mathbf{F}$ & $\begin{array}{l}\text { Reflux; } \\
\text { urinary tract } \\
\text { infection } \\
\text { Reflux: }\end{array}$ & Normal & 1 & 2 & 1 & 12 \\
\hline 27 & 11 & $\mathbf{F}$ & $\begin{array}{l}\text { urinary tract } \\
\text { infection } \\
\text { Reflux; }\end{array}$ & $\begin{array}{l}\text { Normal } \\
\text { Translucent }\end{array}$ & 2 & 2 & 1 & 2 \\
\hline & & & urinary tract & & 3 & 3 & 3 & 2 \\
\hline 29 & 6 & $\mathbf{F}$ & $\begin{array}{l}\text { Reflux; } \\
\text { urinary tract } \\
\text { infection }\end{array}$ & $\begin{array}{l}\text { Solid } \\
\text { lesions; } \\
\text { erythema }\end{array}$ & 3 & 3 & 3 & 2 \\
\hline 29 & 4 & $\mathbf{F}$ & $\begin{array}{l}\text { Reflux; } \\
\text { urinary tract } \\
\text { infection }\end{array}$ & $\begin{array}{l}\text { Translucent } \\
\text { lesions }\end{array}$ & 3 & 3 & 3 & 12 \\
\hline 30 & 7 & $\mathbf{M}$ & $\begin{array}{l}\text { Reflux; } \\
\text { urinary tract } \\
\text { infection }\end{array}$ & $\begin{array}{l}\text { Solid } \\
\text { lesions }\end{array}$ & 2 & 3 & 2 & $<1$ \\
\hline
\end{tabular}

Table I Clinical data, light and electron microscopic appearances, and bacteriological findings in 30 patients

*The cystoscopic specimen of urine in case 3 contained $33 \mathrm{WBC} / \mathrm{cmm}$, probably due to blood contamination.

†These patients had chemotherapy following positive MSU cultures. The bladder biopsy cultures were sterile. 
with $2 \mathrm{mM} \mathrm{Ca}++$ ) for microscopic examination. The other was put in a dry sterile container for culture.

\section{MICROSCOPY}

Following fixation for one hour in glutaraldehyde each fragment was examined under the dissecting microscope and suitable blocks were selected for light and electron microscopy taking care not to damage the epithelium. Tissue for light microscopy was placed in $10 \%$ buffered sucrose solution $(0 \cdot 1 \mathrm{M}$ cacodylate with $2 \mathrm{mM} \mathrm{Ca}++$ ) for 18 hours and taken through graded alcohols and xylene and embedded in paraffin wax. Five-micron sections were stained with haematoxylin and eosin, haematoxylin and van Gieson, Alcian blue periodic acid-Schiff, methyl green-pyronin, Best's carmine (for glycogen), and acidic toluidine blue (for mast cell granules).

Tissue for electron microscopy was placed in a similar $10 \%$ sucrose buffer and postfixed in osmium tetroxide $(1 \%$ OsO4, $10 \%$ sucrose, $0.1 \mathrm{M}$ cacodylate buffer, $\mathrm{pH} 7 \cdot 2$, and $2 \mathrm{mMCa}++$ )for onehour. After a brief wash in sucrose buffer the tissue was dehydrated and embedded in Spurr's resin (Spurr, 1969). Pale gold sections were cut with a diamond knife (Dupont) on a Sorvall Porter Blum mark 2TB ultramicrotome and double stained with uranyl acetate and lead citrate. Sections were examined in an AEI EM 6G electron microscope at $80 \mathrm{Kv}$ with a $250 \mu$ condenser aperture and a $25 \mu$ objective aperture. As a preliminary, $1 \mu$ sections were stained with $0.5 \%$ toluidine blue and examined under the light microscope.

\section{BACTERIOLOGY}

The mucosal fragments were weighed and washed three times in $1 \mathrm{ml}$ sterile distilled water. The tissue was then homogenized in $0.5 \mathrm{ml}$ glucose broth using an all-glass homogenizer. Cultures of measured aliquots of the homogenates, the first and last washings and of the urine sample taken at the time of biopsy, were plated out onto blood agar and MacConkey's medium. Spot cultures were made onto Sabouraud's dextrose agar medium (Oxoid) and the remnants of the homogenates were inoculated into a glucose broth bottle. All cultures were incubated aerobically at $37^{\circ} \mathrm{C}$ and samples plated onto blood agar were also incubated anaerobically using a disposable Gas-Pak (BBL).

The plates were inspected for growth after overnight and 48 hours' incubation and organisms were identified by standard methods. The plates of Sabouraud's medium were kept at room temperature $\left(20-22^{\circ} \mathrm{C}\right)$ for eight days before being discarded and the anaerobic plates were incubated for five days before a negative result was reported. The glucose broth culture if turbid was subcultured for identifi- $\stackrel{\stackrel{0}{\overrightarrow{0}}}{\frac{0}{.}}$ cation.

The urine samples were measured for $\mathrm{pH}$, protein, $\underset{\vec{S}}{\stackrel{\vec{S}}{+}}$ and glucose concentrations using strips of Bili-음 Labstix (Ames). White blood cells were counted in 흠 uncentrifuged urine using a modified Fuchs- $\frac{\bar{D}}{\bar{D}}$ Rosenthal counting chamber and expressed as $\stackrel{\odot}{\circ}$ white blood cells per $\mathrm{cmm}$. Centrifuged deposits were examined microscopically after staining with ${ }^{\infty}$ Geimsa and Gram's stains.

Homogenized bladder tissue and/or urine samples $\overrightarrow{\vec{\omega}}$ from all cases were cultured for $L$ forms of bacteria $\stackrel{\sigma}{\omega}$ using brain-heart-infusion agar medium (Oxoid) stabilized with $0.6 \mathrm{M}$ sucrose and $0.008 \mathrm{M}$ magnesium sulphate (Newsom, 1970). Urine samples were $\stackrel{\infty}{\omega}$ filtered through a $0.22 \mu$ pore Millipore GS filter using a Swinny adaptor fitted to a $10-\mathrm{ml}$ syringe $/$ / before inoculation into L-form medium. In 15 cases $\circ$ virus isolation in tissue culture was attempted using $د$ both homogenized bladder mucosa and urine $z$ samples stored at $4^{\circ} \mathrm{C}$ for a maximum of six hours hefore use.

\section{Results}

CLINICAL

The cystoscopic appearances of the bladder mucosa (table I) were normal in the six boys undergoing operations for repair of hypospadias and in 12 of the control cases. In the remainder mucosal lesions were described as solid or translucent, large (more than $0.5 \mathrm{~cm}$ ) or small. Six bladders also showed areas of erythema and in one patient the mucosa was oedematous.

\section{HISTOLOGY}

The 30 biopsies were divided into three groups on the basis of changes seen in the subepithelial stroma (table II). The first group (L1) comprised 11 cases showing no significant abnormality. The epithelium was three cell layers thick. The superficial one consisted of large flattened cells with eosinophilic granular cytoplasm and large oval vesicular nuclei. The cells of the intermediate and basal layers were $\sigma$ smaller with oval pyknotic nuclei and were arranged $N$ perpendicularly to the basement membrane. Beneath ్ㅗ the epithelium there was a slightly wider band of $\sigma$ connective tissue containing scattered fibroblast nuclei. The deeper tissue was less cellular and con-

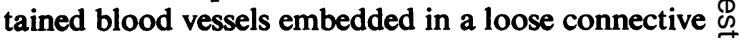
tissue stroma. Three cases with small collections of lymphocytes were included in this group and in $\bar{O}$ sections from eight spocimens mast cells were observed in the superficial stroma.

The second group (L2) consisted of nine cases in which there was diffuse lymphocytic infiltration of 


\begin{tabular}{|c|c|c|c|c|c|c|c|c|}
\hline \multirow[t]{2}{*}{ Group } & \multirow[t]{2}{*}{ Description } & \multirow[t]{2}{*}{ No. of Cases } & \multirow{2}{*}{$\begin{array}{l}\text { Tissue } \\
\text { Polymorphs }\end{array}$} & \multicolumn{2}{|l|}{ Lymphocytes } & \multirow[t]{2}{*}{ Oedema } & \multirow[t]{2}{*}{ Plasma Cells } & \multirow[t]{2}{*}{ Mast Cells } \\
\hline & & & & Diffuse & Focal & & & \\
\hline $\begin{array}{l}\mathbf{L} 1 \\
\mathbf{L} 2\end{array}$ & $\begin{array}{l}\text { No significant } \\
\text { abnormality } \\
\text { Chronic } \\
\text { inflammation } \\
\text { Acute } \\
\text { inflammation }\end{array}$ & $\begin{array}{r}11 \\
9 \\
10\end{array}$ & $\begin{array}{l}\text { Not seen } \\
\text { Not seen } \\
\text { Always present }\end{array}$ & $\begin{array}{l}\text { Not seen } \\
\text { Always present } \\
\text { Always present }\end{array}$ & $\begin{array}{l}\text { Very rare } \\
\text { Rare } \\
\text { Common }\end{array}$ & $\begin{array}{l}\text { Not seen } \\
\text { Occasionally } \\
\text { Common }\end{array}$ & $\begin{array}{l}\text { Not seen } \\
\text { Common } \\
\text { Common }\end{array}$ & $\begin{array}{l}\text { Common } \\
\text { Common } \\
\text { Always present }\end{array}$ \\
\hline
\end{tabular}

Table II Light microscopy appearances in stroma

the superficial stroma. These appearances were considered to indicate chonic inflammation. In four of the cases there was also plasma cell infiltration and in two stromal oedema was evident. In the sections from one biopsy aggregates of lymphocytes were also found. The transitional epithelium was thickened in three cases and in one was infiltrated by lymphocytes.

The remaining 10 cases formed the third group (L3). On account of the finding of neutrophil polymorphonuclear leucocytes in the extravascular tissue of the superficial stroma the appearances were interpreted as acute inflammation. The number of polymorphs varied and in the majority of cases only a few were seen; oedema, with vascular dilatation and congestion, was usually present. In seven cases definite aggregates of lymphocytes were present in the stroma, and four contained germinal centres. Most cases in this group showed thickening of the transitional epithelium and in five neutrophil polymorphonuclear leucocytes were present in the epithelium. No ulceration was seen.

\section{BACTERIOLOGY}

Except for three patients from whom no cystoscopic specimens of urine were received, the patients were divided into three groups (table I).

In group B1 there was no growth on cystoscopic specimens of urine or bladder biopsy culture and there was a WBC count of less than 20 cells $/ \mathrm{cmm}$ of urine. Four cases with negative cultures but having a count of more than $20 \mathrm{WBC}$ comprised group B2, while eight cases yielding growth in the bladder biopsy and/or cystoscopic specimens of urine formed group B3 (table III).

\section{ELECTRON MICROSCOPY}

The specimens obtained from the six boys undergoing repair of hypospadias were well preserved but those from the controls showed much cell separation and shrinkage, presumably due to dilatation of the bladder with water before the biopsy was taken. However, the overall preservation of the internal cell architecture in all specimens was good. In four cases large numbers of bacteria were seen on the outer surface of the epithelium. These were assumed to be contaminants as the specimens were not collected into a sterile fixative. No bacteria were seen within the epithelial cells.

\section{Overall appearance of the epithelium ( $f$ ig 1 )}

No fewer than three cell layers were seen in any specimen but tangential sectioning of the epithelium in the majority made it impossible to determine accurately its thickness. The basal lamina was a continuous layer separating the lamina propria from the epithelial cells which could be divided into basal, intermediate, and superficial types each with a characteristic ultrastructure. Only the basal cells were seen to be attached to the basal lamina. Variable numbers of small lymphocytes were observed within the epithelium. The opposing

\begin{tabular}{|c|c|c|c|c|c|c|}
\hline Case No. & $\begin{array}{l}\text { Bladder Biopsy } \\
\text { (no. organisms/g) }\end{array}$ & & $\begin{array}{l}\text { Cystoscopic Specimen } \\
\text { of Urine (no. organisms/ml) }\end{array}$ & & $\begin{array}{l}\text { White Blood } \\
\text { Cells }(\mathrm{cmm})\end{array}$ & $\begin{array}{l}\text { Precystoscopic Midstream } \\
\text { Urine Specimen }\end{array}$ \\
\hline 14 & Esch. coli & $8.6 \times 10^{3}$ & $\begin{array}{l}\text { Esch. coli } \\
\text { Diphtheroids }\end{array}$ & $\begin{array}{r}>10^{5} \\
10^{2}\end{array}$ & 730 & $\begin{array}{l}\text { Esch. coli } \\
\text { Diphtheroids }\end{array}$ \\
\hline 15 & $\begin{array}{l}\text { Esch. coli } \\
\text { Proteus rettgeri }\end{array}$ & $\begin{array}{r}4 \times 10^{3} \\
3.6 \times 10^{3}\end{array}$ & $\begin{array}{l}\text { Esch. coli } \\
\text { Proteus rettgeri }\end{array}$ & $\begin{array}{r}>10^{6} \\
10^{4}\end{array}$ & 190 & No growth \\
\hline $\begin{array}{l}16 \\
23\end{array}$ & $\begin{array}{l}\text { No growth } \\
\text { Diphtheroids } \\
\text { (Micro-aerophilic) }\end{array}$ & $3 \times 10^{2}$ & $\begin{array}{l}\text { Micrococcus sp. } \\
\text { Diphtheroids } \\
\text { (Micro-aerophilic) }\end{array}$ & $\begin{array}{l}50 \\
20\end{array}$ & $\begin{array}{l}3 \\
5\end{array}$ & $\begin{array}{l}\text { No growth } \\
\text { No growth }\end{array}$ \\
\hline $\begin{array}{l}24 \\
27\end{array}$ & $\begin{array}{l}\text { Strep. faecalis } \\
\text { Diphtheroids } \\
\text { (anaerobic) }\end{array}$ & $\begin{array}{r}10^{4} \\
5 \times 10^{3}\end{array}$ & $\begin{array}{l}\text { Strep. faecalis } \\
\text { Diphtheroids } \\
\text { (anaerobic) }\end{array}$ & $\begin{array}{r}>10^{5} \\
>10^{6} \\
\end{array}$ & $\underset{639}{<1}$ & $\begin{array}{l}\text { Strep. faecalis } \\
\text { Kleb. aerogenes }\end{array}$ \\
\hline $\begin{array}{l}28 \\
29\end{array}$ & $\begin{array}{l}\text { No growth } \\
\text { Esch. coli }\end{array}$ & 20 & $\begin{array}{l}\text { Kleb. aerogenes } \\
\text { Kleb. aerogenes } \\
\text { Not done }\end{array}$ & $\begin{array}{r}10^{6} \\
>10^{5}\end{array}$ & 16 & $\begin{array}{l}\text { Coliform } \\
\text { Esch. coli }\end{array}$ \\
\hline
\end{tabular}

Table III Bacteriological findings in group B3 cases 


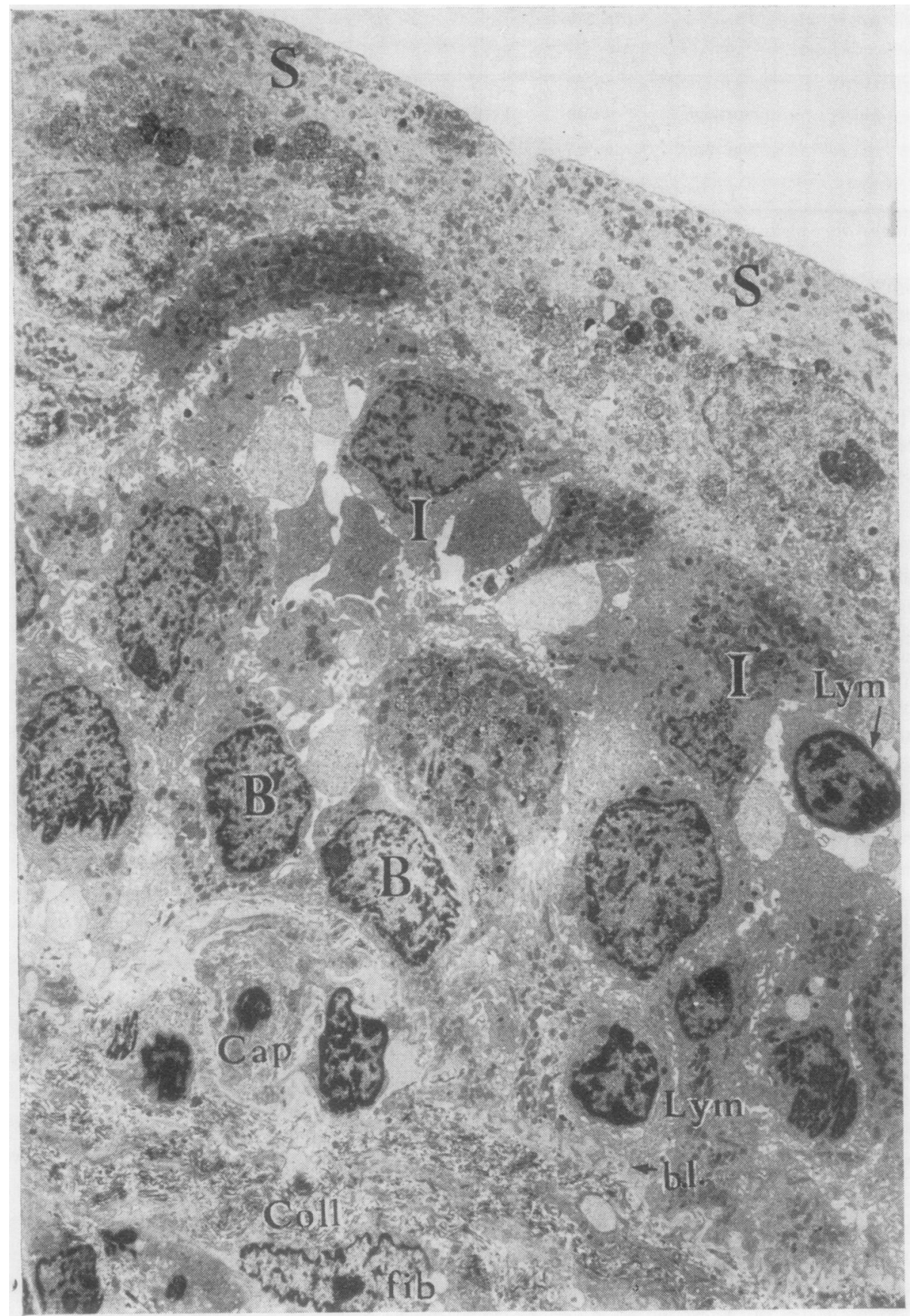


borders of adjacent cells were connected by occasional desmosomes and were usually interdigitated.

\section{Lamina propria}

Immediately underlying the epithelium there was a layer of collagenous material containing many fibroblasts (fig 1). The basement membranes of the numerous capillaries that were present often appeared to merge with the basal lamina of the epithelium.

In all cases there were variable numbers of mast cells present within the lamina propria and plasma cells were observed in material from a few of the control group of cases.

\section{The basal lamina (fig 2)}

This formed a single continuous folded layer, $50-100 \mathrm{~nm}$ in thickness, composed of a lamina densa (20 $\mathrm{nm}$ thick) between electron-translucent zones, separating basal epithelial cells and the lamina propria. The cell membrane adjacent to the basal lamina contained many pinocytotic vesicles and showed patchy accumulations of electron-dense material which resembled half desmosome attachment plates.

\section{Basal cells ( fig 3)}

These were small cuboidal cells in which the nucleus occupied a large part of the cytoplasm, contained marginated condensed chromatin, and was irregular in outline. The nucleolus was prominent, usually in the form of a nucleolonema. Numerous perichromatin granules were situated at the periphery of the chromatin clumps. Nuclear pores could be seen in tangential sections of the nuclear surface and rosettes of ribosomes were attached to the nuclear envelope.

The cytoplasm contained numerous free polysomes and a small amount of endoplasmic reticulum. Secondary lysosomes and glycogen were commonly present and many small mitochondria were situated at the lower pole of the cell. The Golgi apparatus consisted of parallel stacks of four or five cisternae with a few associated vesicles.

\section{Intermediate cells}

These were larger than the basal cells and tended to be elongated in an axis parallel to the basal lamina.

The nucleus had a more regular border then that of the basal cells with less condensed chromatin and a smaller nucleolus. Within any one specimen, the intermediate cells had a similar content of cell organelles, although there was variation between specimens. Three groups of cases (E1, E2, and E3) could be defined on the basis of changes seen both in this layer and in the superficial one (table IV).

In group E1 the most prominent feature was the presence of numerous large, heterogeneoussecondary lysosomes (fig 4) enclosed within a single membrane and within which it was possible to distinguish fragments of membrane. The large Golgi apparatus (fig 5) consisted of multiple stacks of cisternae with vesicular ends but relatively few associated vesicles. In most cells, a few Golgi cisternae showed a thickened membrane with increased electron density;

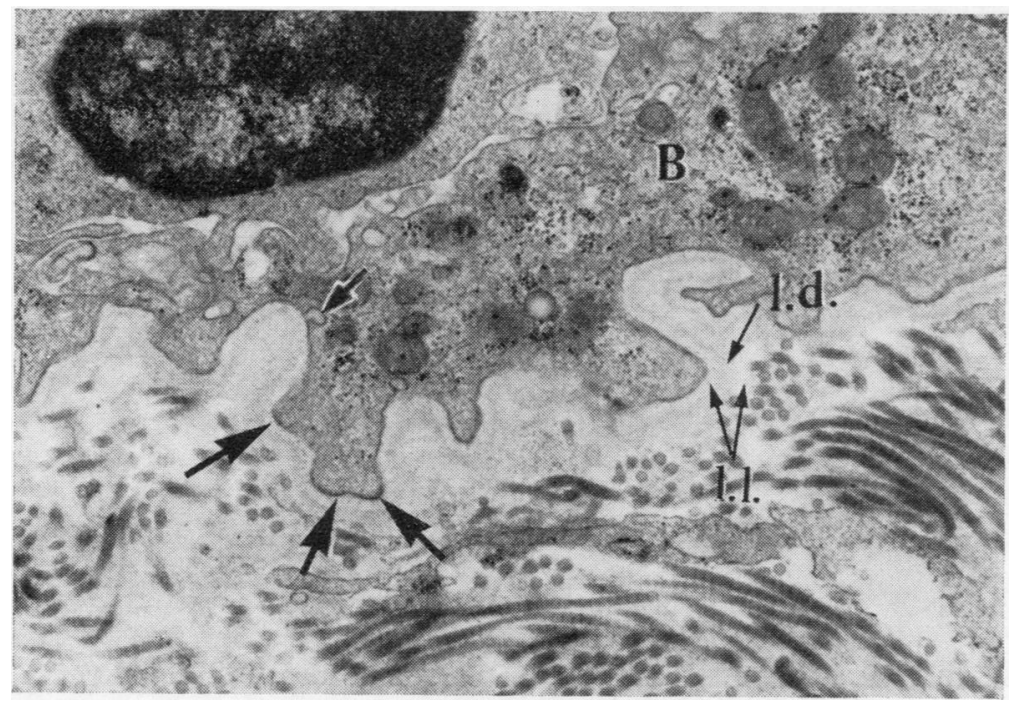

Fig 2 Basal lamina showing lamina densa and laminae lucida (Il). Large arrows mark half desmosomes and the small arrow indicates pinocytotic vesicles. $B$, basal cell. Case $9 \times 18000$. 


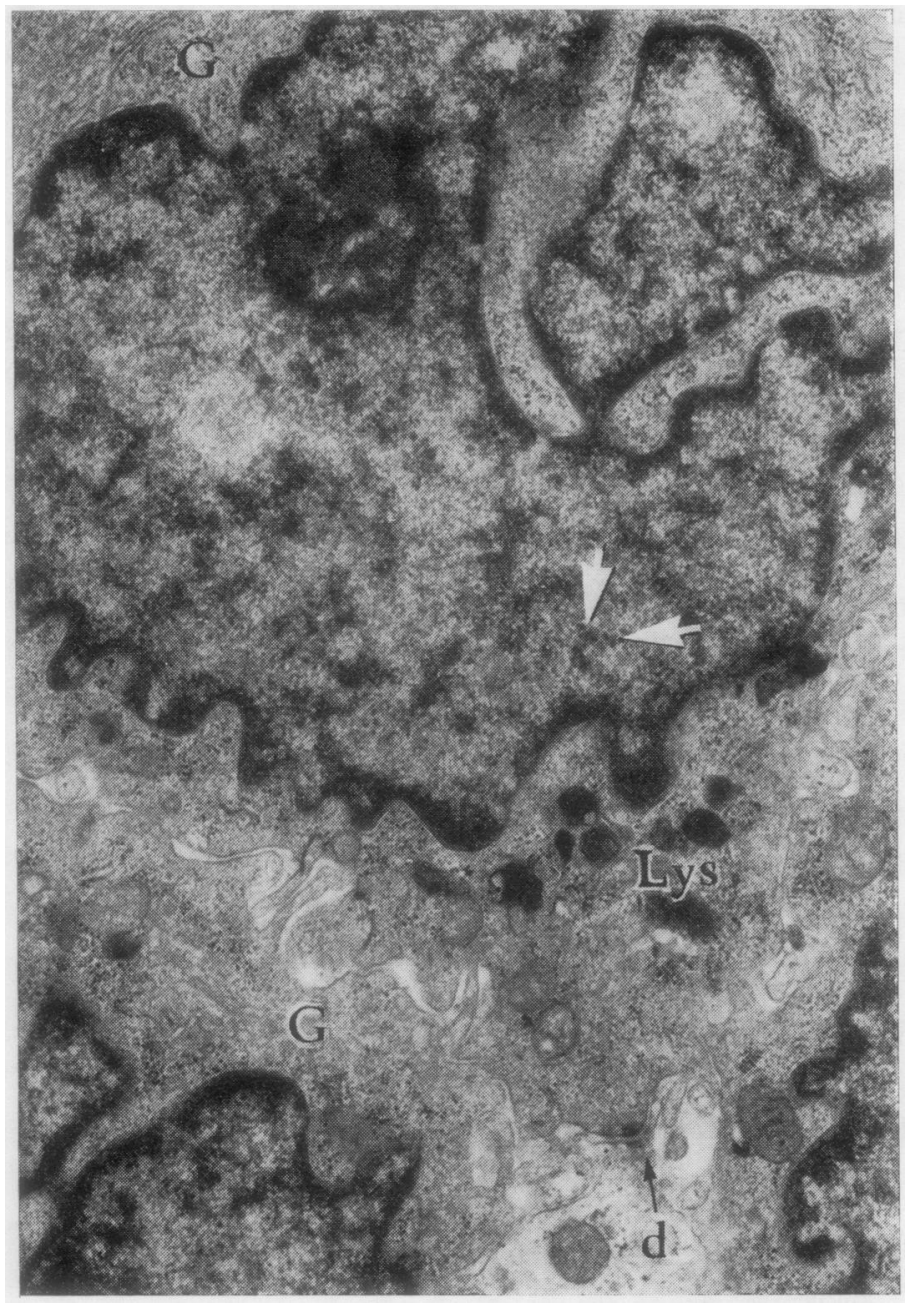

Fig 3 Basal cells showing Golgi apparatus $(G)$, lysosomes (Lys), and desmosomes $(d)$. Arrows indicate perichromatin granules. Case $1 \times 50230$.

\begin{tabular}{|c|c|c|c|c|c|c|c|}
\hline \multirow[t]{2}{*}{ Group } & \multirow[t]{2}{*}{ Case Nos. } & \multirow[t]{2}{*}{ Cell Layer } & \multirow{2}{*}{$\begin{array}{l}\text { Large } \\
\text { Heterogeneous } \\
\text { Secondary } \\
\text { Lysosomes }\end{array}$} & \multicolumn{2}{|l|}{ Golgi Apparatus } & \multirow{2}{*}{$\begin{array}{l}\text { Endoplasmic } \\
\text { Reticulum }\end{array}$} & \multirow{2}{*}{$\begin{array}{l}\text { Pinocytotic } \\
\text { Vesicles }\end{array}$} \\
\hline & & & & Structure & Function & & \\
\hline \multirow[t]{2}{*}{ E1 } & $1-9$ & Superficial & Numerous & Large vesicles & $\begin{array}{l}\text { Luminal surface } \\
\text { membrane } \\
\text { production }\end{array}$ & Scanty & Few \\
\hline & 17,18 & Intermediate & Numerous & Cisternae & $\begin{array}{l}\text { Luminal surface } \\
\text { membrane } \\
\text { production }\end{array}$ & Scanty & Few \\
\hline \multirow[t]{2}{*}{ E2 } & $10-12$ & Superficial & Numerous & Large vesicles & $\begin{array}{l}\text { Luminal surface } \\
\text { membrane } \\
\text { production }\end{array}$ & Scanty & Few \\
\hline & $19-26$ & Intermediate & Few & Cisternae & None apparent & $\begin{array}{l}\text { Moderately } \\
\text { increased }\end{array}$ & Few \\
\hline \multirow[t]{2}{*}{ E3 } & $13-16$ & Superficial & Few & $\begin{array}{l}\text { Cisternae and } \\
\text { small vesicles }\end{array}$ & $\begin{array}{l}\text { Primary } \\
\text { lysosome } \\
\text { production }\end{array}$ & $\begin{array}{l}\text { Moderately } \\
\text { increased }\end{array}$ & $\begin{array}{l}\text { Moderate } \\
\text { numbers }\end{array}$ \\
\hline & $27-30$ & Intermediate & Few & Small vesicles & $\begin{array}{l}\text { Primary } \\
\text { lysosome } \\
\text { production }\end{array}$ & $\begin{array}{l}\text { Greatly } \\
\text { increased }\end{array}$ & Numerous \\
\hline
\end{tabular}

Table IV Electron microscopic appearances in intermediate and superficial cell layers 


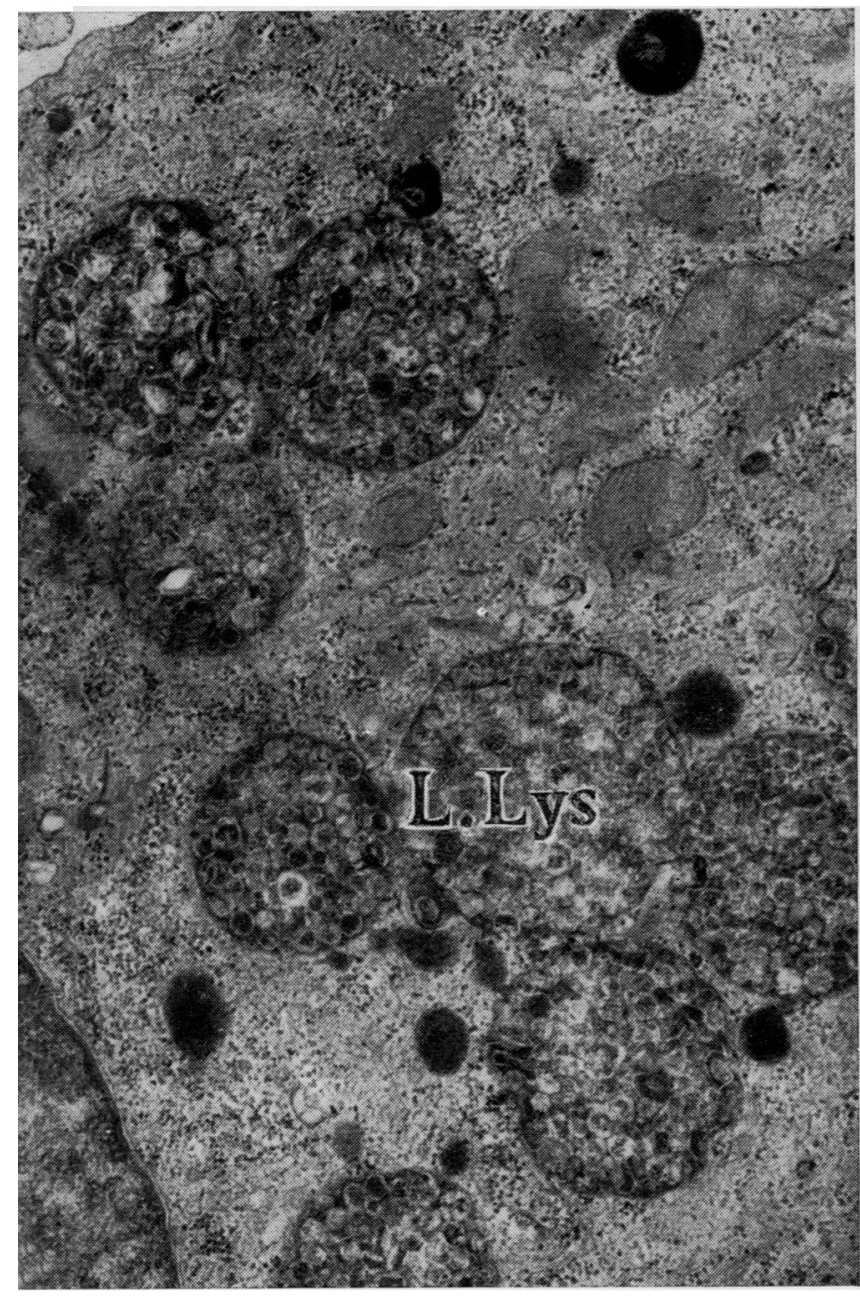

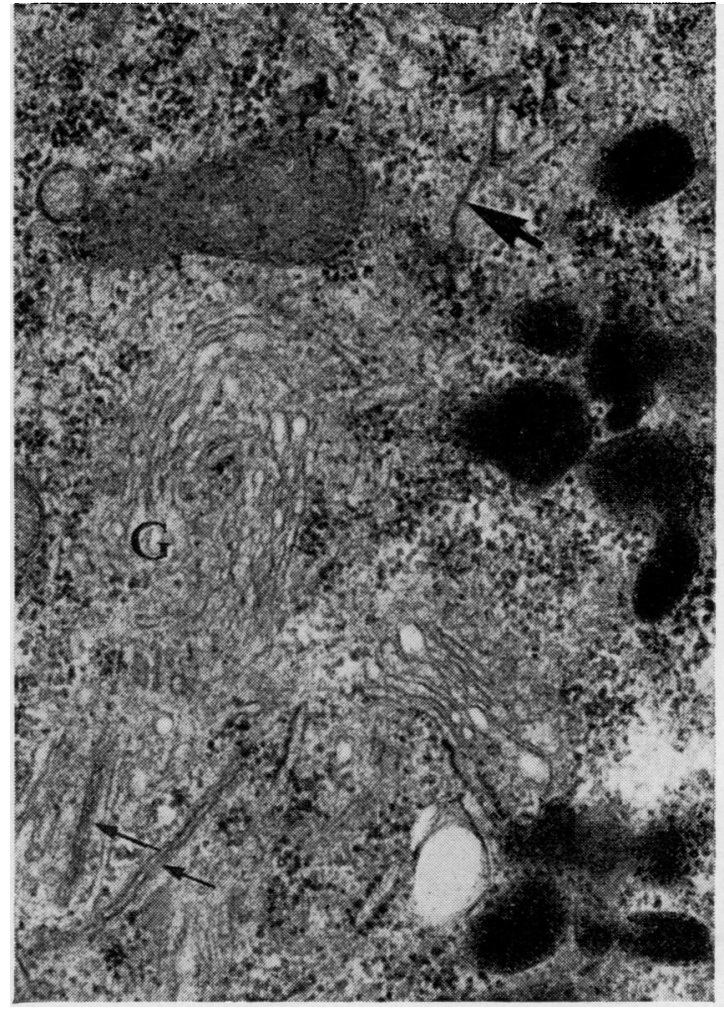

Fig 5

Fig 4 Large heterogeneous secondary lysosomes (L. Lys) in intermediate cells, a feature seen in cases in group E1. Case $8 \times 15800$.

Fig 5 Golgi apparatus $(G)$ consisting of multiple stacks of cisternae with thickened membrane (small arrows); similar thick membrane (large arrows) is present in flattened vesicles. Case $1 \times 39000$.

consisted mainly of small vesicles with a few cisternae; pinocytotic vesicles were numerous at the cell surface.

\section{Superficial cells}

These were large, covering the entire free surface of the epithelium and each overlying two or three deeper cells. The cell shape varied according to the degree of distension of the bladder. Some appeared columnar (fig 7) and others flattened (fig 1) and intermediate forms were seen.

The cell membrane at the luminal surface was approximately $12 \mathrm{~nm}$ in width and had a trilaminar structure in which the inner and outer dense leaflets appeared to be the same width (fig 8). The luminal 


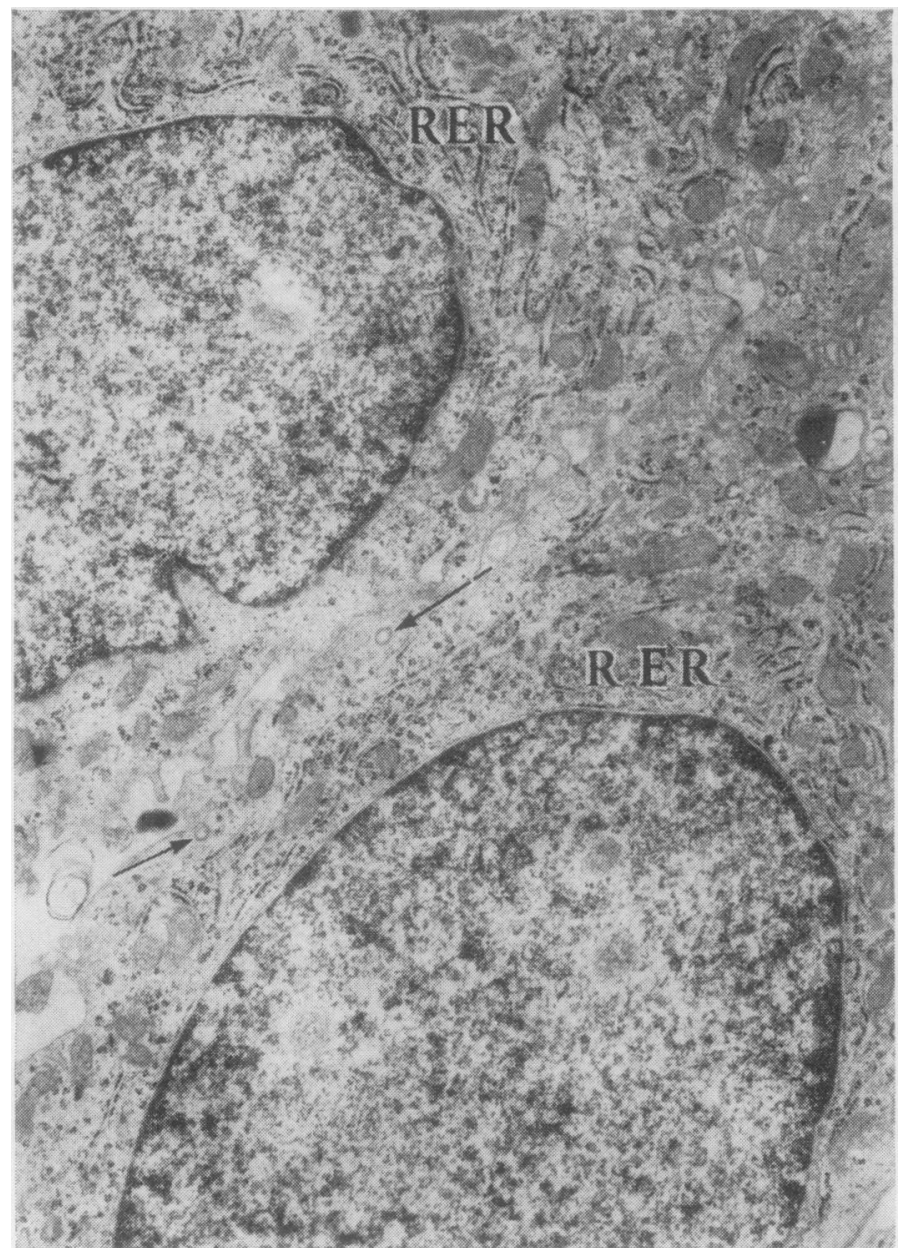

Fig 6 Rough endoplasmic reticulum $(R E R)$ in intermediate layer cells, a feature seen in cases in group E3. Arrows mark pinocytotic vesicles. Case $14 \times 12000$.

Fig 7 Columnar-shaped superficial cells with invagination of the luminal surface (large arrows). Lysosomes $(L L y s)$, mitochondria $(M)$, and junctional complex $(j)$ are also seen. Case $9 \times 4500$.

Fig 7

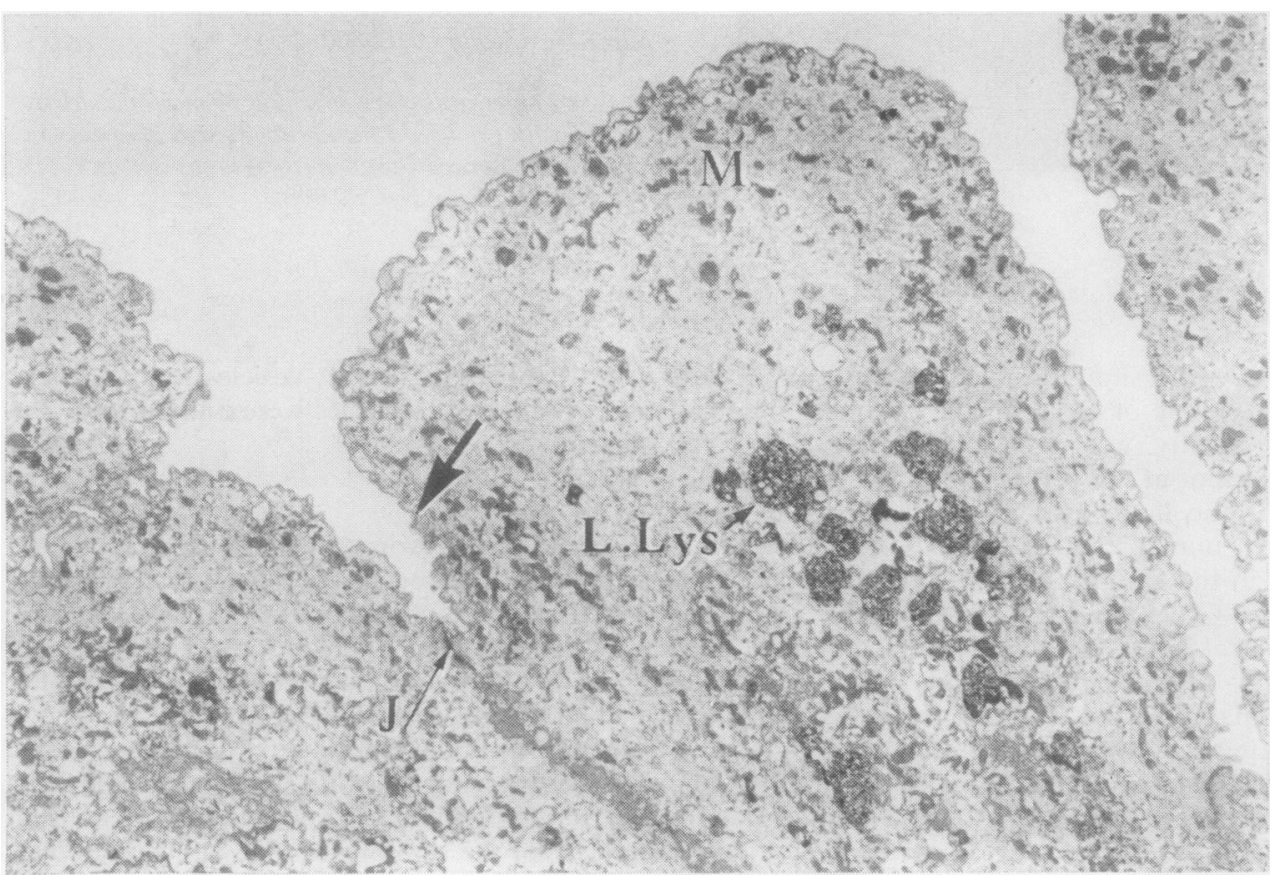




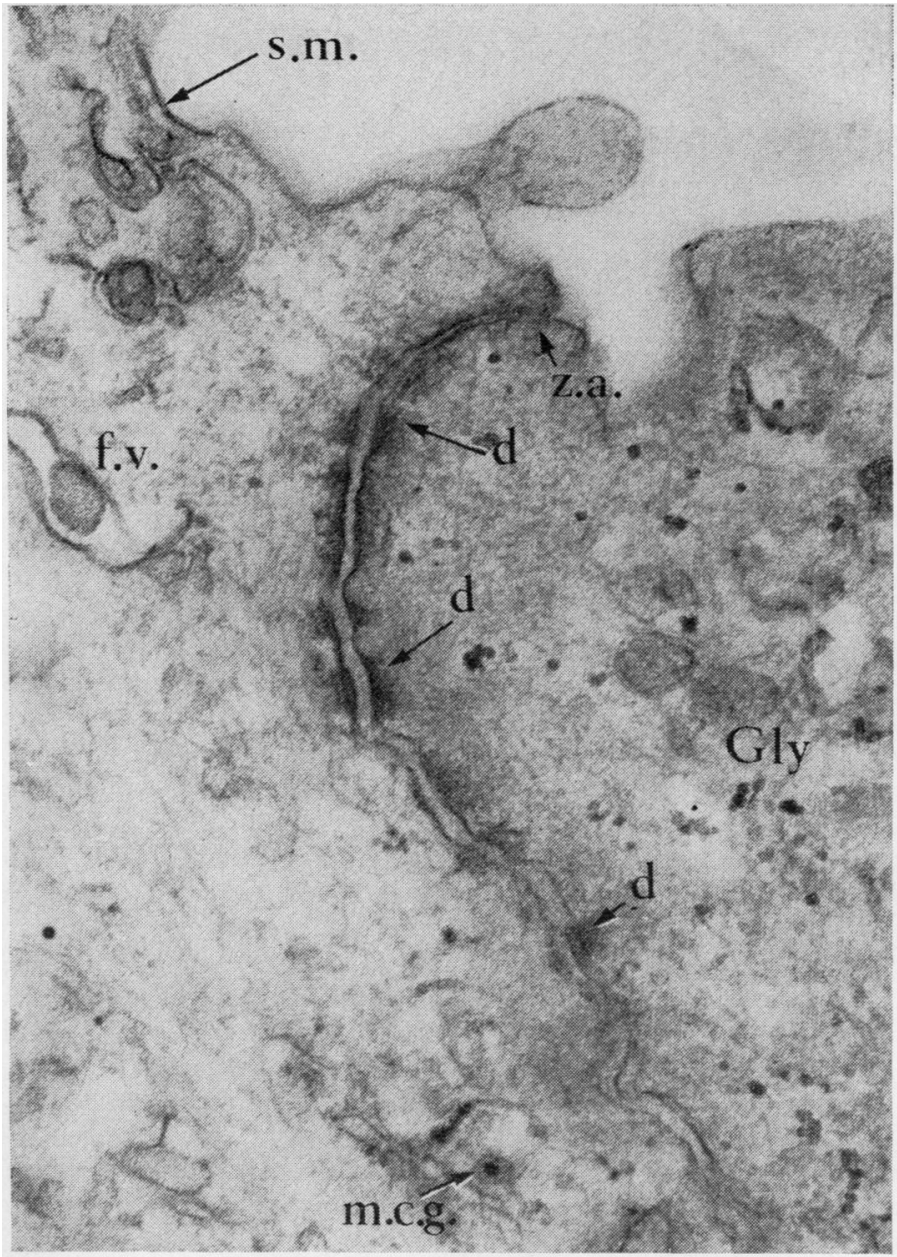

Fig 8 Thick surface membrane (sm) also seen lining a fusiform vesicle (fv). The junctional complex is composed of $a$ zonula adhaerens $(z a)$ and a series of desmosomes (d). Glycogen (Gly) and membrane coating granules $(\mathrm{mcg})$ are also present. Case $9 \times 60000$.

Fig 9 Superficial cell from a case in group E3 showing an increased amount of endoplasmic reticulum. Compare with figure 7. Case $29 \times 12000$.

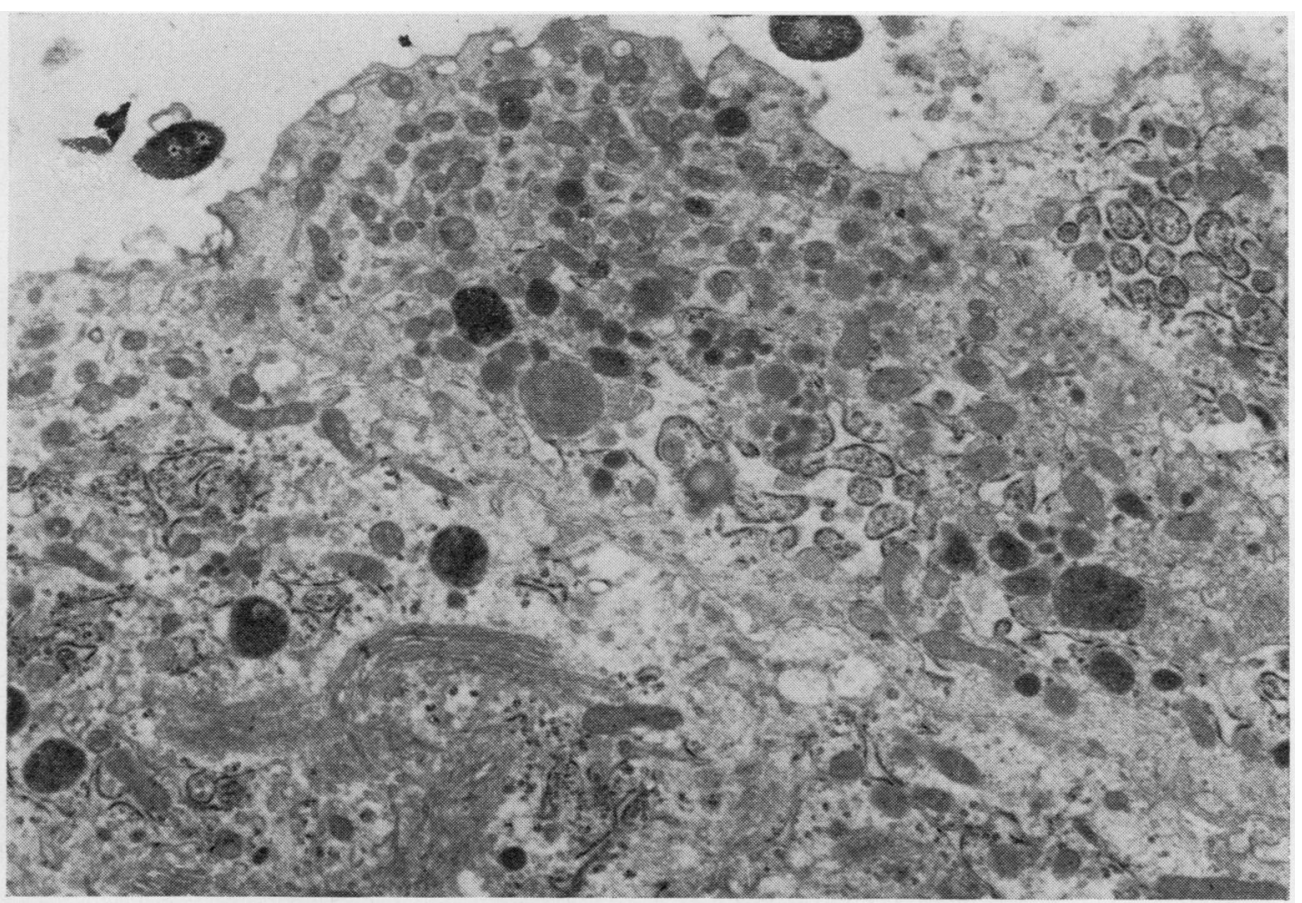


surface was angular in outline, indicating a rigid membrane. Numerous fusiform vesicles, also lined by surface membrane, were present near the luminal surface. At the outer surface adjacent cells were joined by a zonula adhaerens and a series of desmosomes; a zonula occludens was rarely seen.

The nuclei of the superficial cells were large with a smooth outline and contained little condensed chromatin; the nucleolus was small. Mitochondria were numerous and dispersed throughout the luminal surface. Occasional membrane-coating granules (fig 8), consisting of a dense core with a single limiting membrane, were also seen.

In cases from groups E1 and E2 the surface cells contained large numbers of heterogenous secondary lysosomes (fig 7) similar to those described for the intermediate cells. The Golgi apparatus was difficult to distinguish and consisted mainly of large vesicles scattered throughout the cytoplasm.

In cases from group E3, however, fewer lysosomes were seen and there was an increase in the amount of endoplasmic reticulum (fig 9) and pinocytotic activity at the cell surface. The Golgi apparatus was large and consisted of large stacks of cisternae with associated small vesicles.

\section{Discussion}

That the electron microscopic appearance of five of the six boys without urinary infection and undergoing hypospadias repair operations were similar and the bladder mucosa was normal on cystoscopic, light microscopic, and bacteriological examinations (table I) indicated that these patients had healthy bladders. The ultrastructural appearances described, therefore, are those of normal bladder epithelium. In one boy (case 3) urine microscopy revealed 33 WBC per cmm in a heavily bloodstained specimen. As all other findings were normal and the electron microscopic appearances were similar to the other five cases, it is considered that this boy's transitional epithelium is also normal and the high white cell count was probably the result of peripheral blood contamination.

Table V compares electron microscopic and bacteriological findings, including the details of past infection. Seven of the eight group E3 cases were associated with present infection and seven of the 11 group E2 cases were obtained from children with evidence of infection within the last three months but not active at the time of examination. In the majority of cases, therefore, we found good correlation between electron microscopic appearances and infection and the ultrastructural changes observed represent those of acute infection in group E3 and subacute infection in group E2.

\begin{tabular}{|c|c|c|c|c|}
\hline $\begin{array}{l}\text { Electron } \\
\text { Microscopy } \\
\text { Groups }\end{array}$ & $\begin{array}{l}\text { No Previous } \\
\text { Infection }\end{array}$ & $\begin{array}{l}\text { Past } \\
\text { Infection } \\
(>3 \\
\text { months })\end{array}$ & $\begin{array}{l}\text { Recent } \\
\text { Infection } \\
(<3 \\
\text { months })\end{array}$ & $\begin{array}{l}\text { Present } \\
\text { Infection } \\
\text { (Group B3 } \\
\text { or Current } \\
\text { Positive } \\
\text { Midstream } \\
\text { Urine) }\end{array}$ \\
\hline $\begin{array}{l}\text { E1 } \\
\text { E2 } \\
\text { E3 }\end{array}$ & $\begin{array}{l}8 \\
0 \\
0\end{array}$ & $\begin{array}{l}3 \\
1 \\
0\end{array}$ & $\begin{array}{l}0 \\
7 \\
1\end{array}$ & $\begin{array}{l}0 \\
3 \\
7\end{array}$ \\
\hline
\end{tabular}

Table V Cases showing correlation between electron microscopic and bacteriological findings

Less correlation was evident between electron and light microscopic appearances (table I) although five of the eight group E3 cases showed acute inflammation (group L3), the remainder being included in the chronic inflammation group (L2). Light microscopy appeared to be a poor guide to the presence of infection as only half of the 10 group L3 cases had evidence of present infection (group B3 or currently positive MSU), the other five having had infections within the previous three months. These results can be compared with those reported by Marsh, Banerjee, and Panchamia (1974) who used a different system of histological grading and investigated a larger series of cases. They found that definite focal or diffuse lymphocytic infiltration and germinal follicle formation correlated significantly with infection.

Of the clinical descriptions of abnormal bladder mucosa, translucent lesions (also referred to as 'cystitis cystica' by urologists) were observed in six cases (table I) in five of which there was also bacteriological evidence of current infection, the sixth having had an infection two months previously. The appearance of erythema is also associated with the presence of infection as four of the five cases in which this was observed had infection at the time, one case being infected a month previously.

Three papers describe the ultrastructure of normal human bladder epithelium (Battifora et al, 1964; Fulker et al, 1971; Kashiwai, Yano, and Kusunoki, 1963) although in none of these studies were special precautions taken to ensure that the bladder was free of disease. Nevertheless the findings are in general agreement with our description of a threelayered stratified epithelium in which secondary lysosomes are a prominent feature of the superficial and intermediate cell layers. Fulker et al (1971) indicate that in some of their cases they observed the asymmetrical unit membrane of the luminal surface of the superficial cells that is an established feature of the urinary tract epithelium of other mammalian species (Koss, 1969). In the asymmetrical unit membrane the outer (luminal) leaflet of the trilamina membrane is twice as thick as the cystoplasmic 
leaflet and at high magnification has periodic densities due to regularly spaced subunits (Hicks and Ketterer, 1969). In our material, the entire unit membrane of the luminal surface of the superficial cells appeared thicker than that surrounding other parts of the cell (fig 8) but did not appear asymmetrical although in a few cases a beaded pattern could be distinguished. The outer leaflet may be susceptible to artefact except under ideal conditions of fixation such as can be achieved in experimental animals, and we have confirmed the presence of asymmetrical unit membrane in rat ureter perfused with fixative before removal from the dissected specimen. In our human material we observed a similar thick membrane in some Golgi cisternae (fig 5) of the intermediate cells and in the flattened vesicles of the intermediate and superficial layer, thus supporting the findings of Hicks (1966) and Koss (1969) in rats that the Golgi system is probably the site of assembly of the thick plasma membrane which is transported via vesicles to the cell surface.

There have been several suggestions concerning the possible means by which the transitional epithelium accommodates the intermittent expansion and contraction of the urinary bladder. Although no special precautions were taken in our cases to obtain tissue at known degrees of bladder dilatation, the superficial cell layers of different cases showed a variety of contours (compare figs 1 and 7) and invaginations seemed to occur at the site of cell junctions (fig 7).

We did not observe any connexions of the intermediate and superficial cells with the basal lamina which Petry and Amon (1966) suggested would permit contraction and expansion of the epithelium. However, such a sliding action was thought unlikely by Richter and Moize (1963), who studied artificially distended and contracted bladders of four mammalian species, and found that the cells of the three layers elongated in the distended epithelium and that when contraction occurred they became cuboidal in shape and interdigitated. In our material interdigitations between cells thought to be from contracted bladder epithelium (fig 7) were seen and we agree that these probably disappear on expansion.

We observed a small number of membranecoating granules in the superficial cells (fig 8) of the type which Hayward and Hackemann (1973) described as being associated with non-keratinized epithelium. From cytochemical studies these authors consider that the granules contain a glycoprotein which can be discharged onto the luminal plasma membrane. This may be the origin of the mucosubstances that Monis and Dorfman(1967)identified as sialomucins which cover the epithelial surface and which presumably help the waterproofing function of the epithelium.

An increase in the amount of rough endoplasmic reticulum in the cells of the intermediate and superficial layers was present in our cases with acute infection and was also noted by Kashiwai et al (1963) in inflamed human transitional epithelium. Racz, Kaiserling, Tenner, and Wuthe (1973) described the appearances of guinea pig urinary bladder epithelium artificially infected with Listeria monocytogenes in which the organisms become surrounded by endoplasmic reticulum and there is an increase in the number of autophagic lysosomes.

It would appear therefore that the endoplasmic reticulum is stimulated during infection and may thus have a protective function. Tomasi, Tam, Solomon, and Prendergast (1965) have localized the secretory component of IgA to the epithelial cells of the salivary gland using immunofluorescent techniques and we have demonstrated combined IgA in bladder epithelial cells using similar methods. We suggest, therefore, that the endoplasmic reticulum might be the site of origin of the secretory component of $\operatorname{IgA}$.

The small number of secondary lysosomes seen in the intermediate and superficial epithelial cells of the infected cases compared to those present in normal epithelium is a surprising observation but one that can perhaps be related to their specialized function within these cells which Koss (1969) considers is concerned with digestion of excess and used surface membranes. As the Golgi apparatus in the infected cases contains no thickened membrane and only small vesicles and cisternae (table IV), it is likely that little specialized membrane is formed and the need for lysosomal digestion is therefore removed. Lysosomal activity, however, does not cease during infection, as we also observed an increase in the number of Golgi-associated primary lysosomes and it is possible that these organelles contain a bacteriocidal agent which would have a protective function when discharged onto the cell surface.

The authors wish to thank Dr R. C. B. Pugh for advice in preparing the paper and $\mathrm{Mr} \mathrm{D}$. Innes Williams for access to material. One of us (P.A.T.) acknowledges the financial assistance of the Cancer Research Campaign.

\section{References}

Battifora, H., Eisenstein, R., and McDonald, J. H. (1964). The human urinary bladder mucosa. Invest. Urol., 1, 354-361.

Fulker, M. J., Cooper, E. H., and Tanaka, T. (1971). Proliferation and ultrastructure of papillary transitional cell carcinoma of the human bladder. Cancer (Philad.), 27, 71-82.

Hayward, A. F., and Hackemann, M. (1973). Electron microscopy of membrane-coating granules and a cell surface coat in kerati- 
nized and nonkeratinized human oral epithelium. J. ultrastruct. Res., 43, 205-219.

Hicks, R. M. (1966). The function of the golgi complex in transitional epithelium: Synthesis of the thick cell membrane. J. cell. Biol., 30, 623-643.

Hicks, R. M., and Ketterer, B. (1969). Hexagonal lattice of subunits in the thick luminal membrane of the rat urinary bladder. Nature (Lond.), 224, 1304-1305.

Kashiwai, K., Yano, H., and Kusunoki, T. (1963). An electron microscopic study on the transitional cell carcinoma of human urinary bladder. Urol. int., 15, 22-51.

Koss, L. G. (1969). The asymmetric unit membranes of the epithelium of the urinary bladder of the rat. Lab. Invest., 21, 154-168.

Marsh, F. P., Banerjee, R., and Panchamia, P. (1974). The relationship between urinary infection, cytocopic appearance and pathology of the bladder in man. 1. lymphocytes in the lamina propria. J. clin. Path., 27, 297-307.

Monis, B., and Dorfman, H. D. (1967). Some histochemical observations on transitional epithelium of man.J.Histochem. Cytochem., $15,475-481$.
Newsom, S. W. B. (1970). Staphylococcal persisters grown from empyema fluid on L-form medium.J. med. Microbiol., 3, 669-673

Petry, G. and Amon, H. (1966). Licht-und elektronenmikroskopische. Studien über Struktur und Dynamik des Ubergangsepithels. Z. Zellforsch., 69, 587-612.

Racz, P., Kaiserling, E., Tenner, K., and Wuthe, H. H. (1973). Experimental Listeria cystitis. II. Further evidence of the epithelial phase in experimental Listeria infection: an electron microscopic study. Virchows Arch. Abt. B, 13, 24-37.

Richter, W. R., and Moize, S. M. (1963). Electron microscopic observations on the collapsed and distended mammalian urinary bladder (transitional epithelium). J. ultrastruct. Res., 9, 1-9.

Sp urr, A. R. (1969). A low-viscosity epoxy resin embedding medium for electron microscopy. J. ultrastruct. Res., 26, 31-43.

Tomasi, T. B., Jr. Tam, E. M. Solomon, A., and Prendergast, R. A. (1965). Characteristics of an immune system common to certain external secretions. J. exp. Med., 121, 101-124. 